\title{
Contemporary social fuelling the genocide intent: hate speech and hate crimes. Legal remarks for a common definition and related operational preventing mechanisms
}

\author{
Cristiana Carletti
}

This contribution intends to analyze the key elements of the hate speech 'concept': the content and context of the expression; the profile of targeted people; the publicity and potential impact of the expression. The criminal legal nature of hate speech, i.e. the representation of hate crimes within three different European institutional systems will then be under attention in territory where new massive violent conflicts were located in 20th century. Within the Council of Europe the ECtHR case law will be studied in relation to an accepted legal definition of 'hate speech'; within the European Union the need to make hate crime visible is at the core of a greater political will to counter pervasive prejudice against certain groups and to compensate damage caused to victims; for the OSCE/ODIHR hate crimes constitute a serious breach of human rights and have a deep impact on victim communities, threatening domestic and international security.

\section{Key elements of the hate speech 'concept'}

The hate speech 'concept' is at the core of a complex and on-going legal debate which deals with its theoretical opponent, i. e. the freedom of thought, expression and of communication of ideas in terms of disseminating and recipient subjects as members of a social community.

The right to freely express personal opinions is a fundamental human right as codified in international and regional legal instruments as well as in constitutional frameworks of all the Countries within the International Community as a whole. It guarantees the right to "seek, receive and impart information and ideas through any media and regardless of frontiers", as enshrined in Article 19 of the Universal Declaration of Human Rights $\left(\mathrm{UDHR}^{1}\right)$.

As such, it may be considered as a legal feature which is not entirely due to the effects descending thereof in a legal environment: like other universal freedoms, the right to freedom of expression entails exceptions aimed at limiting its implementation in favor of protecting prevailing public and private interest as well as strengthening equality and public order.

Along these lines, the codification of this right has been inspired by an adequate balancing need between a complete exercise of the freedom of expression and

\footnotetext{
${ }^{1}$ See UNGA res. 217A (III), UN Doc. A/810 at 71 (1948). Cfr. P. Weckel, La justice internationale et le soixantième anniversaire de la Déclaration universelle des droits de l'homme, Revue générale de droit international public 2009, p. 5 et seq.; M.B. Baderin/ M. Ssenyonjo, International human rights law: six decades after the UDHR and beyond, 2010; J.-P. Machelon/P. Chaigneau/F. Nohra (sous la direction de), La Déclaration universelle des droits de l'homme: fondement d'une nouvelle justice mondiale?, 2010.
} 
possible limitations if this exercise goes well beyond the fundamental respect of other rights and liberties and stirs up the use of traditional and new means of communication to compress the human dignity and personal security of each human being.

The formulation of this right incorporating a specific reference to an eventual limitation linked to the commission of a hate crime by recurring to hate speech was included since the compilation of the contents of the UN Convention for the elimination of racial discrimination (ICERD), as adopted by UNGA through Resolution 2106A(XX) of 21 December 1965, and entered into force on 4 January 1969. Article 4(a) provides for a comprehensive definition of the main general components of hate speech to be tackled with: the dissemination of ideas based on racial superiority, the dissemination of ideas based on racial hatred, the incitement to racial discrimination and the incitement to commit acts of racially motivated violence. Moreover, Article 4(c) points out that public authorities and institutions have a special obligation to fight against and to abstain from the recourse to any form of promotion or incitement to racial discrimination.

A balancing tentative to make reference to both the above mentioned legal features, the right to freedom of expression and its limitations in terms of hate speech was embraced in the codification of the International Covenant on civil and political rights (ICCPR), adopted by UNGA Resolution 2200A(XXI) of 16 December 1966 and entered into force on 3 January $1976^{2}$. On the one hand, Article 19(2) contains a clear legal definition of the right under examination: "Everyone shall have the right to freedom of expression; this right shall include freedom to seek, receive and impart information and ideas of all kinds, regardless of frontiers, either orally, in writing or in print, in the form of art or through any other media of his choice". On the other side, as established in Article 19(3), possible limited restrictions to freedom of expression are admitted "if provided by law, if they are necessary for the respect of the rights or reputations of others, and for the protection of national security or of public order, or of public health or morals".

Also, an ad hoc formula was introduced in ICCPR in terms of obligation of States Parties to prohibit hate speech: Article 20(2) states that "Any advocacy of national, racial or religious hatred that constitutes incitement to discrimination, hostility or violence shall be prohibited by law". On a general note, if Article 19 guarantees the right to freedom of expression in positive terms, albeit with occasional exceptions and listed limitations, Article 20 imposes an obligation to restrict speech having a hatred ground or motivation. The relationship between these two provisions has been interpreted with the provision that ICCPR State Parties must implement the duty as introduced in Article 20 while not overstepping the permissible scope of limitations on freedom of expression as stated in Article 19; from a complementary approach, these limitations have to be put in place in order to fully observe the obligation introduced in Article 20. In effect, a correspondent commit-

\footnotetext{
${ }^{2}$ See UNGA res. 2200A (XXI), 21 UN GAOR Supp. (No. 16) at 52, UN Doc. A/6316 (1966), 999 UNTS 171 ; 6 ILM 368 (1967).
} 
ment is required of all States Parties according to both Articles 19 and 20: the first one is general and comprehensive in its scope, the second one is in line with the previous, even if focusing on combating every form of hatred speech. In other words, it could be said that the obligations of Article 20(2) are identical or extremely close to the permissions of Article 19(3).

In order to point up in detail the relevant components of the hate speech 'concept' as being completely banned we ought to refer to the observations of the ICERD Committee, as contained in its General Recommendation No. 15 of 23 March 1993 on organized violence based on ethnic violence, in relation to Article 4 of ICERD. The Committee, while reiterating that " $[. .$.$] The proscription of the$ dissemination of ideas of racial superiority, and of organized activity likely to incite persons to racial violence, was properly regarded as crucial. [...] As a result, implementation of Article 4 is now of increased importance", recalls that the provision under consideration has a mandatory legal nature: this means that States Parties must act both to prevent and to repress any act corresponding to the categories reported therein, i. e.: (i) dissemination of ideas based upon racial superiority or hatred; (ii) incitement to racial hatred; (iii) acts of violence against any race or group of persons of another colour or ethnic origin; and (iv) incitement to such acts (Article 4(a)). Two other relevant opinions were expressed by the ICERD Committee in its General Recommendation No. 15: the prohibition of financing of racist activities on the grounds of ethnic and racial motivations by national public authorities (Article 4 (a)); and a proper investigation regarding the promotion or the incitement to racial discrimination by organizations and associations in order to declare the illegal nature of and participation in such activities by these entities.

Following the UN analytical contribution in debating this issue, in more general terms, the hate speech 'concept' may be under analysis by mentioning three keycomponents: the intent, the incitement, and prohibited results following the adoption of such kind of speech ${ }^{3}$.

The intent consists of an advocacy tentative process aimed at inciting hatred, covering also the public statement that has been pronounced. The material component insists on the purpose to promote an idea motivated by racial or discriminatory intent, well beyond the fact that this behaviour is linked with the proper liability of the author. The incitement is based on the voluntary dissemination of ideas, namely those based on superiority and racial hatred but, in several circumstances, an investigation over the nexus between the statement and the prohibited results is required in order to demonstrate the causation and to adopt a proper punishment

\footnotetext{
${ }^{3}$ Cfr. S. Farrior, Molding the Matrix: The Historical and Theoretical Foundations of International Law Concerning Hate Speech, Berkeley Journal of International Law 1996; D. McGoldrick/ T. O'Donnell, Hate speech laws: consistency with national and international human rights law, Legal Studies 1998, p. 453 et seq.; E. Heinze, Viewpoint Absolutism and Hate Speech, The Modern Law Review 2006, p. 543 etseq.; N. Ghanea, The Concept of Racist Hate Speech and its Evolution over time, Paper presented at the United Nations Committee on the Elimination of Racial Discrimination's day of thematic discussion on Racist Hate Speech, 81st session, 28 August 2012, Geneva.
} 
according to the specific context where the incitement was revealed. The causality cannot always be proved so that a standard category of acts may be defined in order to reasonably anticipate the incitement or to suppose that, according to its proper nature, it will raise and generate discrimination. As it concerns the context, it is a very relevant factor to assess if a statement is the logical consequence of an environment of racial hatred where the hate speech refers to contextual elements: these could be well-documented historical facts, established by historians or international or national judiciary systems, but in any case they occurred in a determined place and time and contributed to fueling racial hate through the use of hate speech. Finally, as far as the prohibited results from the recourse to hate speech are concerned, in contrast to the consequences arising from discrimination and violence, as illegal acts punishable according to a general rule prohibiting incitement to crime, the hate crime stands not only as an act but also as an opinion of an individual. This double-track component could be viewed as a complex standard that is not easily proved to find the prohibited 'hatred'. For this reason, according to a theoretical approach, the need to distinguish between expressions targeting ideas, including offensive speech, and abusive expression targeted at human beings, such as hate speech, is needed.

\section{Legal representation of hate crimes and hate speech within three different European institutional systems}

Moving away from a comprehensive overview of the international legal framework relating to the codification of the right of freedom of expression and the resulting obligation of States to prevent and repress hate crimes whenever committed making use of hate speech, a focus on the legal definition of these two legal features is needed within the European regional area due to the common approach adopted in compiling human rights and fundamental freedoms' treaties by the Council of Europe (CoE), in reformulating the EU primary legislation, in adopting soft law recommendations by the competent bodies of the Organization for Security and Co-operation in Europe (OSCE).

\section{Theory and practice: hate crimes and hate speech within the CoE system}

The legal definition aimed at balancing the freedom of expression and possible limitation to implement these rights is contained in Article 10 of the European Convention for the Protection of Human Rights and Fundamental Freedoms (ECHR): "everyone has the right to freedom of expression [including] the freedom to hold opinions and to receive and impart information and ideas without interference by public authority and regardless of frontiers", further mentioning that some restrictions will be provided for that "are necessary in a democratic society, in the interests of national security, territorial integrity or public safety, for the preven- 
tion of disorder or crime, [...] for the protection of the reputation or rights of others".

Among the above-mentioned circumstances restricting the right under examination, the duty to prevent and to repress acts which go well beyond the presumed limitation, exists the prohibition to make use of hate speech, as a means of expressing a proper intent of racially motivated hatred or incitement in regard of the same.

Besides this well known legal instrument, other soft law examples have contributed - inter alia - to a more focused definition of hate speech.

The Recommendation No. R (97) on hate speech adopted by the Committee of Ministers on 30 October 1997, states that the term "shall be understood as covering all forms of expression which spread, incite, promote or justify racial hatred, xenophobia, anti-Semitism or other forms of hatred based on intolerance, including: intolerance expressed by aggressive nationalism and ethnocentrism, discrimination and hostility against minorities, migrants and people of immigrant origin". The Recommendation is aimed at providing Member States with some common criteria to elaborate and implement national legislation in conformity with these regional standards. In particular the gravity of hate speech could be strongly encouraged by recurring to media: along these lines, the effects deriving from committing a hate crime through the dissemination of ideas and principles based on racial motivations may be more harmful and for this reason they require an attentive investigation on the authors of the crime and those who have power over media to incriminate ad personam or in solido. In other terms, the Recommendation outlines the need to clearly distinguish between the responsibility of the author of the expression of hate speech and that of the media for having disseminated racial hatred as an ordinary activity of communicating information and ideas on matters of public interest.

In addition, the Declaration of the Committee of Ministers on freedom of political debate in the media, adopted on 12 February 2004, points out that freedom of political debate does not embrace freedom to express racist opinions or incitement to hatred, xenophobia, anti-Semitism and all forms of intolerance and that in the case of defamation or insult by the media, the descending criminalization of the offence must be necessary and proportional to the gravity of the violation of the rights or reputation of others, in particular whenever other fundamental rights have been seriously violated through defamatory or insulting statements in the media, such as hate speech.

The Recommendation No. 1805 on Blasphemy, religious insults and hate speech against persons on grounds of their religion, adopted on 29 June 2007, by the Parliamentary Assembly refers to the need to criminalize all kind of express manifestation or statements that incite hate, discrimination or violence against individuals or groups on the grounds of religious reasons.

The link between the principle of non discrimination and the religious factor has been at the core of an interesting and on-going debate on the recurrence of hate

\footnotetext{
${ }^{4}$ See European Convention for the Protection of Human Rights and Fundamental Freedoms (ETS No. 5), as entered into force on 3 September 1953.
} 
speech to restrict the freedom of religion and belief. In effect, within the CoE system, this issue was at stake among the topics under the competence and study of the European Commission for Democracy through Law (the so-called Venice Commission), which was tasked to prepare a report on national legislations of Member States concerning blasphemy, insults of a religious nature or incitement to religious hatred. The results of this study culminated in the adoption of the report during the $76^{\text {th }}$ Plenary Session of the Commission, on 17-18 October 2008, and may be summarized as follows: in current democracies each individual or group enjoying the freedom of religion is requested to tolerate criticism in public statements and debates in relation to their respective activities, teaching and beliefs, as long as these critics do not constitute deliberate and unreasonable insults or hate speech, or an incitement to perturb public order, violence or discrimination towards people who practice a specific belief.

The European Commission against Racism and Intolerance (ECRI) has also recommended Member States to criminalize expressions that can be considered hate speech that is racial hatred, notably when it intentionally and publicly incites to violence, to hatred, or discrimination on grounds of race, colour, language, religion, nationality or national or ethnic origin (see General Policy Recommendation $\mathrm{N}^{\circ} 6$ on the topic 'Combating the dissemination of racist, xenophobic and antisemitic material via the internet', adopted on 15 December 2000). The Commission also commended Member States to adapt criminal national legislations to European standards to combat racist expressions, that is public incitement to violence, hatred or discrimination; public insults and defamation or threats against a person or a group of persons on the grounds of their race, colour, language, religion, nationality, or national or ethnic origin; public expression, with a racist aim, of racist ideology or the public denial, with a racist aim, of crimes of genocide, or crimes against humanity or war crimes should also be criminalized by law; public dissemination with a racist aim or material containing racist expression such as the above should also possibly be the object of criminal sanctions (see General Policy Recommendation No. 7 on national legislation to combat racism and racial discrimination, adopted on 13 December 2002). The last non binding instrument adopted by the Commission on 17 March 2005, was the Declaration on the use of racist, antisemitic and xenophobic elements in political discourse, where the ECRI condemns the use of such elements in political discourse and considers such use as "ethically unacceptable",

To complete the CoE legal framework, in recent times, the adoption of the Protocol to the Convention on Cyber Crime, concerning the prosecution of acts of racist and xenophobic nature via computer systems, on 28 January 2003 and which entered into force on 1 March 2006, represents another useful instrument to combat all forms of manifestation and incitement on the grounds of racial and xenophobic hatred disseminated through the so-called new media, i. e. the Internet.

\footnotetext{
${ }^{5}$ See ECRI, Declaration on the use of racist, antisemitic and xenophobic elements in political discourse, as adopted on 17 March 2005, available at http://www.coe.int/t/dghl/monitoring/ecri/activities/themes/racistpolitical_EN.asp.
} 
In effect the fast development of technologies in a globalised world poses a serious challenge for the respect of principles of equality and inclusion while spreading racial and ethnic feelings only by using the website. Along these lines an emergency may be perceived that is the support for racism and xenophobia from those who manage modern and powerful means. There is, therefore, a primary need to amend the domestic legislation in force for each State Party in order to harmonize substantive criminal law in combating racism and xenophobia on the Internet by introducing the following criminal offences: distributing, or otherwise making available, racist and xenophobic material to the public; threatening with the commission of a serious criminal offence, as defined under its domestic law, (i) persons for the reason that they belong to a group, distinguished by race, colour, descent or national or ethnic origin, as well as religion, if used as a pretext for any of these factors, or (ii) a group of persons which is distinguished by any of these characteristics; insulting publicly (i) persons for the reason that they belong to a group distinguished by race, colour, descent or national or ethnic origin, as well as religion, if used as a pretext for any of these factors; or (ii) a group of persons which is distinguished by any of these characteristics; distributing or otherwise making available material which denies, grossly minimizes, approves or justifies acts constituting genocide or crimes against humanity, as defined by international law and recognized as such by final and binding decisions of the International Military Tribunal, established by the London Agreement of 8 August 1945, or of any other international court established by relevant international instruments and whose jurisdiction is recognized by that Party. Furthermore, the Protocol also calls for the full enhancement of procedural and international cooperation provisions contained therein in order to prevent and repress offences of racist and xenophobic propaganda by the exchange of useful best practices and the adoption of common procedures. A very recent initiative has been launched by the CoE on this topic, entitled 'Young People Combating Hate Speech Online": it is a project promoted by the youth sector of the Organization for the period 2012-2014, aiming at combating racism and discrimination disseminated in the form of hate speech through the website and it consists of supporting a European campaign, articulated in national networks, the so-called 'The No Hate Speech Movement", to be joined online by people, starting from the age of 13 , to debate this issue and to propose new methodologies to prevent hate speech online ${ }^{6}$.

The above described legal framework cannot be exhaustive if not completed by a reference to the large case law produced by the European Court of Human Rights (ECtHR) on this issue moving from the assumption that: "[...] tolerance and respect for the equal dignity of all human beings constitute the foundations of a democratic, pluralistic society. That being so, as a matter of principle, it may be considered necessary in certain democratic societies to sanction or even prevent all forms of expression which spread, incite, promote or justify hatred based on intolerance (including religious intolerance), provided that any "formalities", "con-

\footnotetext{
${ }^{6}$ See http://act4hre.coe.int/.
} 
ditions", "restrictions" or "penalties" imposed are proportionate to the legitimate aim pursued"7.

Moving from a vague legal definition of hate speech as far as its criminalization is concerned, the Court has made reference to several forms of expression that spread, incite, promote or justify hatred based on intolerance, also including the religious component. According to a summarizing doctrinal tentative approach in examining the ECtHR case-law, the following different situations may be at stake: "the incitement of racial hatred or in other words, hatred directed against persons or groups of persons on the grounds of belonging to a race; the incitement to hatred on religious grounds, to which incitement to hatred may be equated on the basis of a distinction between believers and non-believers; the incitement to other forms of hatred based on intolerance "expressed by aggressive nationalism and ethnocentrism"” (Council of Europe's Committee of Ministers' Recommendation 97(20) on "hate speech").

The reason of this setting stands for a practical case-by-case approach about the very nature of the expression to be strictly qualified as hate speech: when the formulation entails no doubts about the intent, the incitement and the descending effect and is clearly addressed to an individual or a group, it cannot be protected according to Article 10(2) of the ECHR. Moreover, if the right of freedom of expression is competing with another right laid down in the same Convention and the ultimate aim is the factual violation of this right, the Court may proceed to safeguard the contents of Article 17 of the ECHR, that is preserving the system of democratic values at the core of the Convention while preventing the intent to destroy the right and liberties established therein. As clearly explained by doctrine: "The conflict of rights is therefore resolved either through denial, through the loss of the right to rely on Article 10, under Article 17 of the Convention, or by conciliation, in which case the Court proceeds to a balance of the interests involved" ${ }^{\text {. }}$

This approach is founded on the practical interpretation of Articles 10(2) and 17 respectively. On the one hand, the freedom of expression has been precisely defined by the Court in its Handyside judgment, as follows, further stating the obligations of those who exercise this right: "freedom of expression constitutes one of the essential foundations of such a society, one of the basic conditions for its progress and for the development of every man" and according to a formulation which has since then often been recalled, that "subject to paragraph 2 of Article 10, it is applicable not only to "information" or "ideas" that are favourably received or regarded as inoffensive or as a matter of indifference, but also to those that offend, shock or disturb the State or any sector of the population. Such are the demands of that pluralism, tolerance and broadmindedness without which there is no "democratic society"", On the other, Article 17 is worded in this formulation: "Nothing in this

\footnotetext{
${ }^{7}$ See Gündüz v. Turkey, Application No. 35071/97, Judgment 4 December 2003, margin no 40, CEDH 2003-XI, and Erbakan v. Turkey, Application No. 59405/00, Judgment 6 July 2006, margin no. 56.

${ }^{8}$ See $A$. Weber, Manual on Hate Speech, 2009.

${ }^{9}$ See Handyside v. the United Kingdom, Judgment 7 December 1976, Series A No. 24.
} 
Convention may be interpreted as implying for any State, group or person any right to engage in any activity or perform any act aimed at the destruction of any of the rights and freedoms set forth herein or at their limitation to a greater extent than is provided for in the Convention"; so the main aim of this provision is to guarantee the system of democratic values underlying the Convention and, as validated in the ECtHR case-law, to prevent the abuse of any other right included in the Convention, as firstly reported in the Lawless judgment in examining the relationship between Article 17 and other provisions and progressively detailed in order to determine which form of expression could be considered evidently against the values underlying the Convention but not covered by Article $10^{10}$.

In all circumstances, the Court is requested to take into consideration several factors such as: the objective of the individual whose freedom of speech has been restricted; the content of the expression; the context; the individuals to be considered as targets of the expression; the dissemination and the following potential impact of the expression; the nature and the gravity of the limitation in enjoying the right of freedom of expression.

Among the above cited factors, the key criterion adopted by the Court to determine whether an expression could be defined as hate speech and, for this reason, could be restricted is a joint combination of two: the original aim of the author of the manifestation and the context in which the statement is made. Not only must the intent of the individual to spread racist or discriminatory ideas by recurring to hate speech be a primary focus of attention but also the very offensive nature to determine whether this behavior goes beyond the traditional expressions as contained in Article 10 and, therefore, should not be tolerated in a democratic society and is also excluded from the protection ascertained in Article 17 of the Convention. Along these lines, the Court emphasized that when the author is a politician or a journalist, it is "crucially important that politicians avoid disseminating comments in their public speeches which are likely to foster intolerance" "11, whenever the communication is written press, audiovisual media and broadcasting. Moreover, relevant differences were made by the Court as long as a political discourse or matters of public interest or speeches of religious nature may be restricted, leaving to State Parties a wide margin of appreciation and supervising over motivated reasons to limit the freedom of expression ${ }^{12}$.

When the Court is doubtful about the compliance with Article 17, it may also investigate the limitations to the enjoyment of the right of freedom of expression as codified in the national legislative framework of the State where the case occurred: its aim will be to verify several requirements if eventual restrictions to the freedom of speech have been foreseen by national laws, if these restrictions comply with legitimate purposes set out in Article 10 of the Convention, and, finally, if they are necessary in a democratic society to achieve the objectives contained in Article 10.

\footnotetext{
${ }^{10}$ See Lawless $v$. Ireland, Judgment 1 July 1961, Series A3.

${ }^{11}$ See Erbakan v. Turkey, cit., margin no 64.

${ }^{12}$ See Erbakan v. Turkey, cit., margin no 55; Garaudy v. France, Application No. 65831/01, Judgment 7 July 2003.
} 
In other terms, the Court proceeds in evaluating possible limitations to the right of freedom of expression according to a global perspective, only taking into proper account all the factors and rules when a 'pressing social need' exists while ensuring that they are proportionate to the legitimate aim pursued. When it refers to national legislations in force, a case-by-case approach, including the principle of the margin of appreciation, is required in order to prove whether the expression is perceived as neutral or could offend, shock or disturb individuals as well as groups or the entire population of a State Party. In the past, the Court declared that statements transmitting racial messages or considered to contain racial hatred, such as those denying the Holocaust, need to be restricted to avoid dissemination, to be considered as a denial of crimes against humanity and an incitement to spread hate against the Jewish people.

The ECtHR case law shows us that the Court mainly ruled on the non violation of Article 10, recalling the competent national authorities to adopt a restrictive or a flexible approach in relation to the need to protect (or not) other rights established in the Convention. If the Court ascertains the violation of Article 10, it proceeds to examine whether it is prescribed by law, if it pursues a legitimate aim i. e. to safeguard the general interest (the national security, the territorial integrity or public safety, the prevention of disorder or crime, the protection of health and morals), to guarantee other individual rights (reputation, private life), to preserve the authority and impartiality of the judiciary, and whether the restriction is necessary in a democratic society, that is if there is a 'pressing social need' which calls for a relevant, sufficient, proportionate and consistent limitation by the national authorities under the Court's supervision ${ }^{13}$.

When, on the contrary, the Court was motivated by the opportunity not to limit the right of freedom of expression because of the evaluation on the shocking or offensive nature of the statement, it acted considering the nature itself and the related descending effects, the fact that the statement did not have specific and clearly targeted individuals nor was it perceived as insulting a precise group on the grounds of a common belief, nationality, ethnicity and so on, and the absence of a proper incitement to hatred and violence addressed to such persons.

However, the case-law confirms that the Court, following an attacking and offensive expression aimed at instigating racial hatred in respect of an individual or a group, recognized the opportunity for national authorities to adopt severe limitations to the freedom of expression, in compliance with the requirements provided for in Article 10, also giving priority to the margin of appreciation even if under its constant supervision. Only in several cases the Court adopted a stricter position in regard of politicians and journalists and media in general, in their role of authors of hate speech: on these occasions, the special responsibility in recurring to a language which surely contributes to fueling hatred and intolerance is unacceptable, also including a command responsibility. While the principles of democracy and impartial information on political issues are relevant for public

\footnotetext{
${ }^{13}$ See Handyside v. the United Kingdom, Judgment 7 December 1976, Series A No. 24.
} 
interest, order within a State must be balanced with the right to disseminate and to receive proper communication without overstepping "the protection of the reputation of others".

In other terms, the prohibition of abuse of rights, as stated in Article 17, forbids every statement or comment amounting to hate speech because it violates the fundamental values and principles of the Convention, and asks for an adequate evaluation of the formulation according to Article 10, to determine eventual limitations like the Court stated in Erbakan v. Turkey: "[...] tolerance and respect for the equal dignity of all human beings constitute the foundations of a democratic, pluralistic society. That being so, as a matter of principle it may be considered necessary in certain democratic societies to sanction or even prevent all forms of expression which spread, incite, promote or justify hatred based on intolerance $[\ldots]^{\prime \prime 14}$. Along these lines, the case-law refers to several forms of hate speech to be condemned as they are undoubtedly against the values underlying the Convention according to Article 17: the establishment of "the communist social order by means of a proletarian revolution and the dictatorship of the proletariat" in Communist Party (KPD) v. the Federal Republic of Germany ${ }^{15}$; the promotion of revisionist or negationist statements, as motivated in Honsik v. Austria where "the applicant's publications in a biased and polemical manner far from any scientific objectivity denied the systematic killing of Jews in National Socialist concentration camps by use of toxic gas"16; the fact that "like any other remark directed against the Convention's underlying values ..., the justification of a pro-Nazi policy could not be allowed to enjoy the protection afforded by Article 10", as reported in Lehideux and Isorni, further asserting that "it does not appear that the applicants attempted to deny or revise what they themselves referred to in their publication as "Nazi atrocities and persecutions" or "German omnipotence and barbarism"17; the fact that "Denying crimes against humanity is therefore one of the most serious forms of racial defamation of Jews and of incitement to hatred of them. The denial or rewriting of this type of historical fact undermines the values on which the fight against racism and anti-Semitism are based and constitutes a serious threat to public order. Such acts are incompatible with democracy and human rights because they infringe the rights of others. Its proponents indisputably have designs that fall into the category of aims prohibited by Article 17 of the Convention", as was clearly motivated in the Garaudy case ${ }^{18}$.

Several cases have been dealt with by the Court in connection with statements that amount to a proper racial hate speech, in violation of Article 17: the decision of the European Commission of Human Rights, followed by the European Court, in

\footnotetext{
${ }^{14}$ See Erbakan v. Turkey, cit., margin no 56.

${ }^{15}$ See Communist Party (KPD) v. the Federal Republic of Germany, Judgment 20 July 1957, Yearbook 1, p. 222.

${ }^{16}$ See Honsik v. Austria, Application No. 25062/94, decision of the Commission 18 October 1995, D. R. 83, pp. 77-85.

${ }^{17}$ See Lehideux and Isorni v. France [GC], Judgment 23 September 1998, Reports of Judgments and Decisions, 1998-VII, para. 47.

${ }^{18}$ See Garaudy v. France, Application No. 65831/01, Judgment 24 June 2003.
} 
the case Glimmerveen and Hagenbeek $v$. the Netherlands ${ }^{19}$, or the conclusions of the Court in Jersild, Norwood v. the United Kingdom ${ }^{20}$ and Pavel Ivanov v. Russia ${ }^{21}$, asserting that policy statements including elements of racial discrimination, in contrast with values of tolerance, social peace and non discrimination underlying the Convention, cannot be framed according to Article 10 but to Article 17.

\section{The visibility of hate crimes within the EU: data and policies}

After the entry into force of the Lisbon Treaty, the freedom of thought, conscience and religion as well as the freedom of expression and information have been enshrined in Articles 10 and 11 of the European Charter of Fundamental Rights, as proclaimed and revised in 2007 and now having a binding legal nature within the new EU normative framework, and must be examined in connection with Article 21 which reiterates the substantive contents of the European acquis as far as the principle of non discrimination ${ }^{22}$.

In contrast to the research methodology adopted with reference to the CoE, a first legal exploration on the relationship between Articles 11 and 21 of the EU Charter will be carried out in order to introduce the key pillars in reference to the fundamental rights and freedoms under attention. The following analysis will deal with the need to make hate crimes visible through a proper inquiry recently promoted and reported by the European Fundamental Rights Agency (FRA) and with the on-going political challenge moving from the adoption of the Framework Decision on combating certain forms and expressions of racism and xenophobia by means of criminal law, adopted on November 28, 2008.

Article 11 of the EU Charter states that "1. Everyone has the right to freedom of expression. This right shall include freedom to hold opinions and to receive and impart information and ideas without interference by public authority and regardless of frontiers. 2. The freedom and pluralism of the media shall be respected". The separation of the components of these freedoms in two paragraphs is the outcome deriving from the development of media as a dynamic means to communicate opinions and ideas in society.

On the one hand, paragraph 1 of Article 11 entails a comprehensive protection of the process of forming individually and expressing collectively opinions that may be

\footnotetext{
${ }^{19}$ See Glimmerveen and Hagenbeek v. the Netherlands, Applications Nos. 8348/78 and 8406/78, decision of the Commission 11 October 1979, D. R. 18, p. 187.

${ }^{20}$ See Jersild v. Denmark [GC], Judgment 23 September 1994, Series A No. 298.

${ }^{21}$ See Pavel Ivanov v. Russia, No. 35222/04, decision of 20 February 2007.

${ }^{22}$ See inter alia: M. Bell, The principle of equal treatment: widening and deepening, in: P. Craig/ G. De Búrca G. (eds.), The evolution of EU law, 2011, p. 611 et seq.; M. De Mol, The Novel Approach of the CJEU on the Horizontal Direct Effect of the EU Principle of Non-Discrimination: (Unbridled) Expansionism of EU Law?, Maastricht Journal of European and Comparative Law 2011, p. 109 et seq.; S. Fredman, Discrimination law, 2011; E. Ellis/P. Watson, EU anti-discrimination law, 2012; J. Croon, Comparative Institutional Analysis, the European Court of Justice and the General Principle of Non-Discrimination-or-Alternative Tales on Equality Reasoning, European Law Journal 2013, p. 153 et seq.; C. Tobler, The Prohibition of Discrimination in the Union's Layered System of Equality Law: From Early Staff Cases to the Mangold Approach, in The Court of Justice and the Construction of Europe: Analyses and Perspectives on Sixty Years of Case-law - La Cour de Justice et la Construction de l'Europe: Analyses et Perspectives de Soixante Ans de Jurisprudence, 2013, p. 443 et seq.
} 
considered as the basic condition to exercise the freedom of expression. This also means that opinions could not only be statements but information to be disseminated through all means of communication and that freedom of expression could include free speech, free press, free artistic and literary forms. The adopted formula contains both the passive and active aspect, i. e. the right to receive and impart all kinds of information. The explanation of this provision confirms a correspondence with Article 10 of the ECHR and, pursuant to Article 52(3) of the Charter, because of the same meaning and scope of this right, possible limitations should be in conformity with those provided for in Article 10(2) and without prejudice to any restrictions imposed by the EU law on Member States. Moreover, by recalling Article 53 of the Charter, the interpretation of its provisions depend on international law, international treaties to which all the EU Member States are contracting parties, the EU law - jointly considered as EU Treaties and secondary law, and finally on national Constitutions and legal statutes in Europe. Along the lines of the above mentioned correspondence between the EU Charter and the ECHR, Article 11(1) does not contain specific categories or forms of freedom of expression but some of them may well replicate those ones judged by the ECtHR: 'information and ideas concerning matters ... of public interest', 'information and ideas on political issues' and artistic expression.

On the other hand, the freedom and pluralism of the media, as established in Article 11(2), includes printed press, radio and television as well as the new media, i. e. the Internet. Besides this economic interpretation of the content of paragraph 2 according to ECJ case-law, as reported in the explanation mentioning the need to protect the freedom of media insofar as they provide services in compliance with Article 49 of the EEC Treaty, as reaffirmed in Council Directive 89/552/EEC of 3 October 1989, and the Protocol on the System of Public Broadcasting in the Member States annexed to the EC Treaty, the protection of the principle of pluralism is further reinforced citing ECJ judgment in the Stichting Collectieve Antennevoorziening Gounda case ${ }^{23}$. This approach can be interpreted in relation to the aim of respecting this freedom by the EU and of guaranteeing it by Member States as well. In effect, both the EU and national institutions and authorities are requested to provide for possible limitations in the exercise of the freedom of media not through Article 52(3) of the EU Charter referring to Article 10 of the ECHR but through Article 52(1): in other terms, any limitation on the exercise of this right must be provided for by law and respect the substantive contents of the freedom of media, must be necessary and must meet the objectives of general interest recognized by the EU or the need to protect the rights and freedoms of others.

The linkage among Articles 10,11 and 21 of the EU Charter could lead the way for the evaluation of the opportunity to adopt secondary legislation aimed at reaffirming the principle of non discrimination while combating all discriminatory

\footnotetext{
${ }^{23}$ See European Court of Justice (ECJ) 25. 7. 1991, case 288/89 (Stichting Collectieve Antennevoorziening Gouda and others / Commissariaat voor de Media) [1991]ECR 4007.
} 
forms listed in Article 21 or to suggest that Member States enact anti-discrimination legislation at domestic level.

In effect, a bottom-up approach has been registered resulting in the adoption of EU secondary legislation as a comprehensive tentative approach to harmonizing national laws within each EU Member State to fight against racism, xenophobia and related intolerance, aiming also at criminalizing racist and xenophobic hate speech and at providing for an aggravating circumstance for crimes having a racist or xenophobic motivation. At the same time, the path to penalizing these crimes favoured EU institutions in pursuing their efforts to ensure the conformity of national laws with the EU secondary legislation: to achieve this scope, both an inclusive investigation on the various forms and manifestations of racial hatred and the elaboration of an ad hoc legal instrument to combat racist and xenophobic attitudes within the European area have been considered as relevant and complementary means.

The first objective was achieved by the European Fundamental Rights Agency in 2012 by releasing a report entitled 'Making hate crime visible in the European Union: acknowledging victims' rights', that deals with the issue under examination according to a comparative analysis on national laws in force, reporting individual cases when a hate crime was committed and introducing an inclusive official data collection survey involving the $27 \mathrm{EU}$ Member States as a consequence of the high percentage of people as targets of hate speech because of their - perceived or real origins, nationality, beliefs or cultures ${ }^{24}$.

The key-research approach consists of the reported violation of fundamental rights as enshrined in the EU primary law, insofar as it was represented by verbal abuse, physical attack or murder motivated by prejudice. Along these lines, official data collection mechanisms adopted at the national level have been classified according to the limited, good, comprehensive nature and transparency of data. The data quality is interpreted as comprehensive where, despite the modalities of reporting and recording crimes, there is not a higher rate of hate crimes within a country and it is ascertained efficiently and transparently in the publishing phase. On the contrary, when data are limited because of a low rate of reporting, recording and prosecuting, hate crimes have been not properly contrasted. Good data entail an appreciable mechanism to report and record hate crimes, even if, at the publishing stage, a partial gap of data collection is registered that could contribute to capture at best the real situation.

The findings confirm that both direct victims and indirect witnesses of hate crimes are generally reluctant to report them to competent public authorities or alternative civil society organizations, and this is the main cause for the invisibility of the phenomenon, contributing to lack of reporting and prosecuting those who are responsible for the commission of these crimes. This under-reporting is also, as we mentioned supra, the result of very dissimilar domestic mechanisms to collect data,

\footnotetext{
${ }^{24}$ See http://fra.europa.eu/en/publication/2012/making-hate-crime-visible-european-union-acknowledgingvictims-rights.
} 
to record and evaluate them in relation to bias motivations, and of course to publish comprehensive statistical data about hate crimes.

The report suggests to national referees to build a coherent and efficient mechanism to include data on the number of incidents reported by victims and recorded by competent authorities in order to properly manage the following sanctions relating to the proved offence. This information could be well complemented by also referring to other crime victimization surveys beyond the legal clarification of hate crimes, due to the spreading condition of multiple discrimination offences.

On one side it means that, whenever possible, official data should include references to the nature and the extent of non reported crimes, to the individual experience of the victims and to their reasons for non-reporting. This, as explained in the Report, aims to "make hate crime visible in the EU; give victims of hate crime the opportunity to seek redress against perpetrators; ensure that EU Member States respond effectively to hate crimes as an abuse of fundamental rights". The reception of advice is probably needed to broaden the scope of the official data collection on hate crimes by introducing multiple references to the nature of what is recorded, the time-frame of the recording, the yearly up-dating of collecting mechanisms, new legislative measures to improve data collection while respecting the socio-historical development of the same mechanisms, and the concrete will of EU Member States to acknowledge and combat hate crimes.

On the other side, it stands for the fact that law enforcement officials should take into proper account the bias motivation, that legislators should provide for clear-cut definitions of hate crimes and for adequate penalties to severely punish those committing this kind of offences, that the judiciary clearly sentences the bias motivation to raise awareness regarding the phenomenon and to induce deterrence in relation to the possible commission of a hate crime. Only by supporting these multiple actors' action, victims and witnesses are really encouraged to report crimes, increasing their confidence in the ability of the public system at all, as well as their opportunities to seek redress against offenders decisively and effectively.

Besides the need to delineate in a comprehensive manner the phenomenon of hate crimes at national level, the duty to contribute and to implement EU secondary law at domestic level is the other relevant recommendation included in the above mentioned Report and to be considered as a complementary legislative action to harmonize the issue under focus.

In this sense, the Council Framework Decision 2008/913/JHA of 28 November 2008 , on combating certain forms and expressions of racism and xenophobia by means of criminal law could be read to support the process aimed at giving more visibility to hate crimes, also in the perspective of its review to be completed within November $2013^{25}$.

The Framework Decision requires EU Member States to take all the necessary measures to ensure a more severe punishment following an offence motivated by racism or xenophobia along an EU approach as far as the harmonization of criminal

\footnotetext{
${ }^{25}$ See Council Framework Decision 2008/913/JHA of 28 November 2008, in OJ 2008 L 328/556.
} 
law and criminal justice mechanisms is concerned. In particular, it provides that: the punishment must concern a public incitement to violence or hatred addressed to an individual or a group on the grounds of race, colour, religion, descent or national or ethnic origin, and must be effective, proportionate and dissuasive in relation to the committed crime.

Article 1 in fact states that: "1. Each Member State shall take the measures necessary to ensure that the following intentional conduct is punishable: (a) publicly inciting to violence or hatred directed against a group of persons or a member of such a group defined by reference to race, colour, religion, descent or national or ethnic origin; (b) the commission of an act referred to in point (a) by public dissemination or distribution of tracts, pictures or other material; (c) publicly condoning, denying or grossly trivialising crimes of genocide, crimes against humanity and war crimes as defined in Articles 6, 7 and 8 of the Statute of the International Criminal Court, directed against a group of persons or a member of such a group defined by reference to race, colour, religion, descent or national or ethnic origin when the conduct is carried out in a manner likely to incite to violence or hatred against such a group or a member of such a group; (d) publicly condoning, denying or grossly trivialising the crimes defined in Article 6 of the Charter of the International Military Tribunal appended to the London Agreement of 8 August 1945, directed against a group of persons or a member of such a group defined by reference to race, colour, religion, descent or national or ethnic origin when the conduct is carried out in a manner likely to incite to violence or hatred against such a group or a member of such a group".

According to Article 1, the relationship between the perpetrator and the victim could be featured both directly, i. e. when the first labels the second in a discriminatory manner, and indirectly, that is by intentionally publicly threatening or inciting others to commit hate crimes against an individual or a group (Article 1, (a) and (b)), by publicly but not intentionally (as necessarily) condoning, denying or trivializing crimes including the hatred component (Article 1, (c) and (d)). This entails that EU Member States shall provide for a maximum criminal sanction of no less than one to three years of imprisonment for natural persons, and both criminal or non-criminal fines for legal persons, including also the exclusion from public benefits or aid, the disqualification from performing commercial activities, the judicial supervision or judicial winding-up orders.

Moreover Article 1(2) provides for the EU Member States to limit legal protection to conducts "carried out in a manner that likely to disturb public order": it is an additional and unnecessary component of the public manifestation on the ground of racial hatred and it will not be further perceived as such by the interested individual or group.

Article 4 also establishes that EU Member States shall adopt measures to enhance the severity of the punishment for other criminal offences on the grounds of hatred and prejudice, considering the offence as an aggravating circumstance, otherwise requesting the domestic courts to act to assume an adequate sanction. This formula- 
tion implies the opportunity to include grounds such as anti-Semitism, sexual orientation or disability, to give a wider and significant meaning to the offence under attention, according to Article 21 of the EU Charter and to Article 14 of the EHRC at the international level and to national laws promulgated at the domestic level. In effect, several EU Countries have created ad hoc qualifications of crimes being severely punished otherwise the racist and xenophobic motivation is pursued as an aggravating circumstance among many others: in this second hypothesis this could lead to a less proper consideration of hate crime during a proceeding and is a fragile deterrent following the lack for an harsher punishment of the perpetrator.

To sum up, the Framework Decision does not entail absorbing all the motivations of an offence in a consolidated legal feature, but to suggest determining a comprehensive legal framework and asking competent national authorities, both the normative power and the judiciary, to take into proper consideration each motivation on racial, xenophobic or discriminatory hatred when judging in a given case.

\section{Hate crimes as a potential threat to domestic and international security from the OSCE perspective}

The OSCE region is a geographic area experienced in problems of hate crime and violence committed against individuals and groups on the grounds of a bias motivation, especially when it is caused by a feeling of superiority hatred constituting a serious breach of human rights and perpetrated on victims with the aim of undermining domestic, regional and international security as well as social stability while fueling community conflicts and wider-scale violence.

This widespread condition has called and calls at present for OSCE intervention to contrast hate crimes and incidents motivated by racism, xenophobia and related intolerance, often determined by ethnic and religious hatred by a preventing and repressing approach, pursuing against a progressively broader instability and unrest or in favour of the re-establishment of political and social stability in the postconflict stage ${ }^{26}$.

Since 1990, when at the Copenhagen Meeting of the Conference on the Human Dimension of the CSCE participating States pledged to adopt protection measures to prevent any act constituting incitement or violence against a group on national, racial, ethnic, religious discrimination or hatred, further concerns were expressed about crimes based on prejudice, discrimination, hostility or hatred also at the CSCE Meeting of Experts on National Minorities; but the term 'hate crimes' was

\footnotetext{
${ }^{26}$ See ODIHR, Combating Hate Crimes in the OSCE Region. An Overview of Statistics, Legislation, and National Initiatives, Warsaw 2005; ODIHR, Hate Crimes in the OSCE Region. Incidents and Responses, Annual Report for 2006, Warsaw 2007; ODIHR, Hate Crimes in the OSCE Region. Incidents and Responses, Annual Report for 2007, Warsaw 2008; ODIHR, Hate Crimes in the OSCE Region. Incidents and Responses, Annual Report for 2008, Warsaw 2009; ODIHR, Preventing and Responding to Hate Crimes, a Resource Guide for NGOs in the OSCE Region, Warsaw 2009; ODIHR, Supplementary Human Dimension Meeting on "Hate Crimes Effective Implementation of Legislation", 4-5 May 2009, Vienna, Final Report, Vienna 2009, PC.SHDM.GAL/13/ 09; ODIHR, Hate Crimes in the OSCE Region. Incidents and Responses, Annual Report for 2009, Warsaw 2010. See also U. Kinitz, The Duties and Role of the Police in Combating Hate Crimes, OSCE Yearbook 2007, p. 217 et seq.
} 
explicitly quoted in an OSCE Ministerial Council Decision adopted in 2003 (No. 4), recalling States' commitment to enact domestic legislations covering crimes 'fuelled by intolerance and discrimination'.

In effect, key principles at the core of the definition of the contents of an OSCE agenda on this issue have been precisely introduced within its legal framework in recent times by support of institutional bodies such as the Office for Democratic Institutions and Human Rights (ODIHR) as well as those of OSCE Member States.

ODIHR was recommended by the Ministerial Council to combat hate crimes through hate crime data collection, completed by making all useful information publicly available through the Tolerance and Non-Discrimination Information System, by promoting the diffusion of its report on Challenges and Responses to Hate-Motivated Incidents in the OSCE Region, by assisting Member States in alerting, identifying and reporting on hate-motivated incidents (MC Decision No. 13/06), also focusing on the use of the Internet intended to fuel bias-motivated violence (MC Decision No. 9/09).

The Ministerial Council further recommended to Member States to implement relevant commitments relating to hate crimes such as: the enactment of tailored legislative measures to combat hate crimes (MC Decision No. 9/09), public condemnation with reference both to political discourse and general propaganda in the media and on the Internet (MC Decision No. 4/03, No. 12/04, No. 9/09), establishment of institutional and operational mechanisms at the domestic level to collect information and statistics on hate crimes and to translate them to ODIHR, or to provide for appropriate training for public officials, in particular law enforcement officials (MC Decision No. 10/05, No. 10/07, No. 9/09), strengthening the monitoring role and contribution from the civil society (MC Decision No. 13/06, No. 10/07, No. 9/09), providing victims with access to counselling and proper legal assistance (MC Decision No. 9/09).

Besides the need to introduce a clear legal definition of hate crimes and to provide for a comprehensive strategy to prevent and repress them, both OSCE institutional bodies and Member States have gradually contributed to the achievement of this aim also through the establishment of a network composed of National Points of Contact on Combating Hate Crimes, asking for the participation of representatives from civil society and anti-discrimination bodies, as well as the adoption in March 2009 and related dissemination of the ODIHR Legislative Guidelines on hate crimes, developed in consultation with several experts from the judiciary, governmental bodies, academia and civil society ${ }^{27}$.

Along the above mentioned premises, the issue is under the specific attention of the Organization as a whole and its Member States according to four strategic keypillars: the adoption of legislative measures aiming at contrasting and repressing hate crimes both generally and specifically; the reinforcement of the judiciary and the improvement of prosecution of hate crimes at the domestic level and related training addressed to public officials and law enforcement officials; data collection and related

${ }^{27}$ See ODIHR Legislative Guidelines on hate crimes, available at http://www.osce.org/odihr/50732. 
awareness raising educational promoted initiatives; a more active participation of the civil society to collect, monitor and analyze data on the topic at stake.

As it concerns the promotion of a comprehensive legislation at national level, providing for a proper definition of the offence and related penalties for accountable perpetrators, it essentially depends on the intent or motivation determining the crime and entails an unambiguous distinction among incitement (hate speech), act (hate crime) and discriminatory attitude or behaviour, beyond the victim's race, ethnicity, gender, sexual orientation, religion, mental and physical disability. The above cited ODIHR Guidelines suggested answering the following questions to solve possible legal doubts: "1) whether hate crimes are a specific category of crime or, alternatively, whether a hate motive is treated as an aggravating factor in sentencing for "ordinary" crimes; 2) which groups should be legally protected against hate crimes (e.g., are lesbian, gay, bisexual and transgender people included); 3) whether the law applies only if motive of hate or hostility can be shown, or if it also applies in any situation in which a victim was selected because of membership in a protected group; 4) whether the law covers crimes against persons associated or perceived to be affiliated with protected groups; and 5) how much evidence of motive is needed for charges to be filed?".

In effect, if all these questions lead to a positive answer, the enactment of a proper legislative framework has to provide for the punishment not only of the offence (incitement or act, as a hate incident) but also of the aggravating circumstance of having a bias motivation (as a hate-motivated incident). This, of course, calls for a harsher penalty. In other terms, if the hate crime is composed of a first element, that is the constitution of a criminal offence under ordinary criminal law, and of a second element, that is the target of the same offence i. e. a characteristic individual or a group, the latter must be considered as determining an aggravating criminal offence under extraordinary or special criminal law, in relation both to the direct victim or victims and to potential victims in the perspective of escalating patterns of violence.

In keeping with this standpoint, the OSCE/ODIHR and Member States contributed to the legal categorization of several manifestations of hate crimes, engaging for the enactment or the review of existing legislations in favour of tailored legislative measures: the intolerant discourse inflaming social tensions against targeted groups by recurring to racist and xenophobic propaganda (Ministerial Council Decision No. 13/06); the discriminatory speech addressed to targeted groups based on an ethnic or religious motivation, as recalled in several statements and commitments adopted during subsequent Ministerial Council meetings from Copenhagen in 1990 until the OSCE High-Level Conference on Tolerance and Non-discrimination, held in Astana in 2010.

In particular, it has been the case of "anti-Semitic incidents in the OSCE area making full use of all reliable information available" and "incidents motivated by racism, xenophobia, or related intolerance, including against Muslims" or even "fighting prejudice, intolerance and discrimination against Christians and members of other religions". All these incidents manifestly contributed to increasing political 
and social tensions and undermining international and regional stability of the OSCE region.

Another relevant fear was reported in OSCE/ODIHR monitoring activities: the hate crimes committed by identity groups and the neo-Nazis phenomenon. Due to the planned and complex serious criminal action made by these actors, a reinforced international co-operation is required for, moving from a harmonization of previous domestic legislations in force and including targeted investigations by specialized units, further prospecting an educational strategy regarding Nazism and post-World War II extremist ideologies.

As far as the reinforcement of the judiciary and the improvement of prosecution of hate crimes at the domestic level and related training addressed to public officials and law enforcement officials are concerned, the OSCE/ODIHR reported in recent years the difficulties encountered depending on the type of offence to be properly investigated, the lack of specialist police units to be specifically instructed to identify, inquiry and register bias motivations before the courts, and the complexity to adequately prosecute hate crimes by the same courts.

For all these reasons, sufficiently funded professional training and capacity building activities within OSCE Member States are required for combating hate crimes, giving public officials, prosecutors and judges very precise instructions about their work in terms of recording and investigating hate crimes. This further means that they are recommended to promptly investigate hate crimes, to publicly condemn the perpetrators, to encourage reporting by direct victims and third parties, to ensure co-operation mechanisms and develop targeted prevention programmes and initiatives (such the ODIHR Programme on Training against Hate Crimes for Law Enforcement), to promote awareness-raising and education towards the communities and the civil society.

As already recalled, the issue of data collection about the hate crimes' phenomenon is without doubt at the core of the OSCE strategies. It is inextricably connected with practical obstacles experienced both by the official systems of monitoring and public reporting and by the victims of hate crimes.

On a general note, a higher ratio of hate crimes committed in a determined country does not mean that the phenomenon is particularly serious in absolute terms: the collected and evaluated data may simply reflect a broader legal definition of hate crimes and this condition has a stronger impact in the national recording data system. To achieve a comprehensive and factual overview of the phenomenon two conditions need to be satisfied. On one hand, official monitoring and reporting systems should include anonymous and disaggregated information on bias motivations and/or victims - as an individual or groups, and should record incidents, offenses and related prosecutions: according to this approach alone the most vulnerable victims emerge and this entails public officials adopting a careful systemic procedure to categorize and not to separate data according to a presumed hierarchy based on the type of offence or victim. On the other, the assumption of underreporting due to the lack of identification of the crime as a hate crime by the victim 
or to the lack of confidence about reporting to a third party or to public officials has to be properly tackled with, including the guarantee to protect the information by the same law enforcement agents as an essential step for a wider investigation or to prevent further hate crimes.

To sum up, an appropriate data collection methodology must be adopted at the national level, including precise references to: competent authorities collecting data, bias motivations, types of crimes under recording, public information and public use of data, number of reported disaggregated hate crimes by police forces and/or prosecutors, number of reported hate crimes including hate speech, hate incidents and/or discriminatory acts.

Lastly, a more active participation of the civil society to collect, monitor and analyze data on hate crimes is called for. The role of civil society is also highly valuable in assisting victims of hate crimes. These two functions have been automatically included in OSCE/ODIHR strategies concerning the cooperation with non institutional actors.

In effect, the supplementary aid from civil society has to be facilitated to counter incitement or violence as hate crimes because of its local recognition and early warning vocational competence on issues of social concern and practical follow-up intervention on incidents. Moreover, civil society plays a relevant role in developing initiatives and educational projects aimed at building the community confidence in law-enforcement agencies and at encouraging the reporting of hate crimes.

Without any doubt, civil society organizations and associations have a longstanding experience in terms of public awareness-raising and of implementing education programmes promoting tolerance, non discrimination and human rights protection addressed not only to victims but to communities at large, completed by the advocacy function aimed at fostering the establishment of national bodies competent for the development and implementation of national plans on this issue. At present, this competence also needs to be widely supported in a proper and effective manner.

\section{Concluding remarks Key elements of the hate speech 'concept'}

The analysis of each institutional system in this contribution may lead to the following concluding observations: while the CoE adopted a double approach aimed at legally defining and prosecuting hate crimes and hate speech, the EU pursued the need to study the phenomenon to find adequate political strategies to cope with it, and the OSCE tried to assume it as a potential threat to domestic and international security in the European regional area; three diverging but complementary perspectives, that must be jointly investigated to deal with the phenomenon in a comprehensive manner. 